\title{
Rheological behavior of concentrated tucupi
}

\author{
Telma dos Santos COSTA ${ }^{\mathrm{a}}$, Antonio Manoel da Cruz RODRIGUES ${ }^{\mathrm{a}, \mathrm{b}}$, Rosinelson da Silva PENA ${ }^{\mathrm{a}, \mathrm{b}^{*}}$
}

\begin{abstract}
Tucupi, which is widely enjoyed in the North region of Brazil, is a fermented liquid derived from cassava (Manihot esculenta Crantz) and has been taken abroad for its exotic characteristics. This study aimed to assess the rheological behavior of tucupi with 30,35 , and $40 \%$ solids and concentrated at 50,70 , and $90^{\circ} \mathrm{C}$. The rheological data were obtained at $25,40,60$, and $80{ }^{\circ} \mathrm{C}$ with increasing and decreasing shear rates. Rheology at $25^{\circ} \mathrm{C}$ indicated that the partial gelification of starch during concentration causes a decrease in the product's viscosity and, if the concentration is carried out at a temperature that favors total starch gelification, the product's viscosity increases. Concentrated tucupi behaved as a pseudoplastic fluid, but at 60 and $80{ }^{\circ} \mathrm{C}$ with increasing shear rates, the product behaved as a dilatant fluid. Hysteresis were observed in flow curves starting at $40^{\circ} \mathrm{C}$, which characterizes concentrated tucupi as a rheopectic fluid. The Ostwald-de Waele model predicted the product's flow curves and an Arrhenius-like equation described the dependence of temperature on apparent viscosity for the rheological data obtained with increasing shear rates. The product's activation energy $\left(\mathrm{E}_{\mathrm{a}}\right)$ values ranged from 16.86 to $25.23 \mathrm{~kJ} / \mathrm{mol}$ as a function of concentration.
\end{abstract}

Keywords: Manihot esculenta; cassava wastewater; concentration; temperature; rheopectic fluid.

Practical application: Concentration and temperature have influence on the rheological behavior of tucupi.

\section{Introduction}

Tucupi, a fermented product obtained from cassava (Manihot esculenta Crantz) roots, is produced and widely consumed in the North region of Brazil as an ingredient to prepare several foods and as sauces (Costa et al., 2017a; Costa et al., 2017b; Pires \& Silva Pena, 2017). Although tucupi has low $\mathrm{pH}(3.0-3.4)$ and high acidity (3.9 - $10.7 \mathrm{meq} \mathrm{NaOH} / 100 \mathrm{~mL})$, it is a liquid product and, hence, virtually entirely water (94.6 - 97.5\% moisture), which makes it prone to biochemical and microbiological spoilage processes (Chisté et al., 2007).

Liquid foods are often concentrated as a preservation method and this is a key step for the industry when dealing with fluid products with low solids content, particularly as a pre-treatment for drying. The concentration process decreases the product's volume and weight, which results in lower storage, packaging, and shipping costs. Water activity also decreases, which increases microbiological and biochemical stability (Brennan et al., 1999; Silva et al., 2005; Vasconcelos \& Melo Filho, 2010). Concentrating tucupi is an alternative for better product preservation and for enabling its use in new food products.

Knowing the physical phenomena associated with the flow (plastic deformation) of fluid foods is of uttermost importance for designing and sizing equipment such as pumps and pipes, stirrers, heat exchangers, homogenizers, and extruders, among others. These parameters are also important for quality control, for defining conditions to process and store the product, and for establishing the product's shelf life (Steffe, 1996; Rao, 1999; Abu-Jdayil et al., 2002; Silva et al., 2005).

The rheological behavior of a fluid can be Newtonian or non-Newtonian, whether dependent or independent of time, given its origin, composition, and structural behavior (Rao, 2014). During processing, storage, shipping, and consumption, a fluid food's concentration and temperature may vary, which makes it important to know its rheological properties as a function of these parameters (Ibarz \& Cánovas, 2002). Such information is important for the sizing of unit operations such as thermal treatment and concentration (Silva et al., 2005).

Tucupi is a product frequently used in the form of concentrated sauces. Thus, since the scientific literature carries no information on the rheology of concentrated tucupi, this research aimed to investigate the product's rheological behavior at different concentrations and obtained at different concentration temperatures, as well as to assess the effect of temperature on the product's rheology.

\section{Material and methods \\ 2.1 Sample}

The tucupi used in the research was obtained from a producer in the city of Acará ( $1^{\circ} 57^{\prime} 39^{\prime \prime} \mathrm{S}$ and $48^{\circ} 11^{\prime} 48^{\prime \prime} \mathrm{W}$ ), Pará, Brazil. The study used boiled tucupi with no added spices or sodium chloride. 


\subsection{Tucupi concentration}

The tucupi was concentrated in a rotary evaporator (Marconi, São Paulo, Brazil) coupled to a vacuum pump (Quimis, 60 LPM, São Paulo, Brazil). The product was concentrated at low pressure at 50,70 , and $90^{\circ} \mathrm{C}$ until the solids contents were 30,35 , and $40 \%$. After the samples were concentrated, they were stored in amber flasks under refrigeration $\left(\approx 5^{\circ} \mathrm{C}\right)$ until the analyses.

\subsection{Concentrated tucupi characterization}

In order to characterize the concentrated tucupi, total solids, $\mathrm{pH}$, total titratable acidity, and starch content were determined according to the Association of Official Analytical Chemists (2010). All analyses were carried out in triplicate.

\subsection{Rheological measures}

The rheological data of concentrated tucupi were obtained with a rheometer (Brookfield, R/S PLUS - SST, Massachusetts, USA) coupled to a temperature-controlled bath (Lauda Ecoline, RE 200, New Jersey, USA) and connected to a computerized system for data acquisition. The experimental data were obtained using the $\mathrm{CR}$ (Controlled-Rate) mode with the shear rate ranging from 0 to $450 \mathrm{~s}^{-1}$ (ascending curve - up ramp) and from 450 to $0 \mathrm{~s}^{-1}$ (descending curve - down ramp). A cone-plate system with C50-1 spindle and $1 \mathrm{~mm}$ spacing was used. The rheological curves were obtained at $25,40,60$, and $80^{\circ} \mathrm{C}$ and all assays were carried out in triplicate. Both tucupi and products based on tucupi are, in general, preserved at room temperature $\left(\mathrm{T}>25^{\circ} \mathrm{C}\right)$, which has motivated the use of temperatures starting at $25^{\circ} \mathrm{C}$ in this study.

\subsection{Mathematical modeling}

In order to predict tucupi's rheological behavior in the different conditions studied, the goodness-of-fit of the Newton model (Equation 1) and Ostwald-de Waele model (Equation 2) to the experimental data was assessed. Only these models were used since the flow curves showed no initial stress for the product to start flowing within the experimental domain. The fits were performed by non-linear regression analysis, using Levenberg-Marquardt methodology and convergence criterion of $10^{-6}$. The coefficient of determination $\left(\mathrm{R}^{2}\right)$, the reduced chi-squared value $\left(\chi^{2}\right)$, and the root mean square error (RMSE) were the parameters used to evaluate the fits. The values for the parameters of the fits of the rheological models to the experimental data underwent analysis of variance (ANOVA) and a complementary Tukey's test to compare the means at $5 \%$ significance $(\mathrm{p} \leq 0.05)$.

$$
\begin{aligned}
& \tau=\eta \cdot \gamma \\
& \tau=\mathrm{k} \cdot \gamma^{\mathrm{n}}
\end{aligned}
$$

where, $\tau=$ shear stress $(\mathrm{Pa}) ; \gamma=$ shear rate $\left(\mathrm{s}^{-1}\right) ; \eta=$ viscosity (Pa.s); $\mathrm{k}=$ consistency index $\left(\mathrm{Pa} . \mathrm{s}^{\mathrm{n}}\right)$; and $\mathrm{n}=$ behavior index.

The apparent viscosity $\left(\eta_{\mathrm{a}}\right)$ values were calculated by Equation 3 using the values of $\tau$ calculated with the model that presented the best fit to the flow experimental data. The effect of temperature on apparent viscosity was assessed by an Arrhenius-like equation (Equation 4) (Steffe, 1996). From the angular coefficient of the linear regression of $\eta_{\mathrm{a}}$ versus $1 / \mathrm{T}$, the product's activation energy $\left(E_{a}\right)$ value was obtained. The regression used $\eta_{a}$ values determined for a shear rate of $100 \mathrm{~s}^{-1}$ for every work temperature $\left(25-80^{\circ} \mathrm{C}\right)$.

$\eta_{a}=\frac{\tau}{\gamma}$

$k=A \cdot e^{\frac{-E_{a}}{R T}}$

where, $\eta_{\mathrm{a}}=$ apparent viscosity (Pa.s); $A=$ Arrhenius constant (non-dimensional); $\mathrm{E}_{\mathrm{a}}=$ activation energy $(\mathrm{kJ} / \mathrm{mol}) ; \mathrm{R}=$ universal gas constant $(8.314 \mathrm{~J} / \mathrm{mol} . \mathrm{K})$; and $\mathrm{T}=$ absolute temperature $(\mathrm{K})$.

\section{Results and discussion}

\subsection{Concentrated tucupi characterization}

The concentrated products, with 30 and $40 \%$ total solids, had the following characteristics, respectively: $\mathrm{pH}$ of $3.94 \pm 0.01$ and $3.24 \pm 0.01$, total acidity of $72.74 \pm 0.87$ and $90.18 \pm 0.05$ meq NaOH/100 mL, and $5.82 \pm 0.31$ and $7.76 \pm 0.42 \%$ starch.

\subsection{Rheological behavior of concentrated tucupi}

The flow curves ( $\tau$ versus $\gamma$ ) and viscosity curves ( $\eta$ versus $\gamma$ ) obtained at $25^{\circ} \mathrm{C}$ for the concentrated tucupi are presented in Figure 1, where the effect of concentration and of concentration temperature on the product's rheological behavior can be seen. According to the behavior of the curves, both the increase in concentration and in concentration temperature of tucupi impacted the product's rheological behavior at $25^{\circ} \mathrm{C}$. Overall, concentration presented a greater effect on the product's rheological behavior, but the increase in concentration become more evident the effect of concentration temperature.

As a whole, concentrated tucupi's stress (Figure 1A) and viscosity (Figure 1B) decreased as concentration temperature increased for a constant $\gamma$ value. However, the flow and viscosity curves obtained for the product concentrated at $90^{\circ} \mathrm{C}$ are above those obtained for the product concentrated at $70{ }^{\circ} \mathrm{C}$, which suggests higher stresses and viscosities for the former throughout the shear rate range studied. This behavior can be attributed to the gelification and downgrading of the starch in the product. According to Hoover (2001), cassava starch gelification occurs between 57 and $84^{\circ} \mathrm{C}$. That allows stating that no starch gelification took place in the product concentrated at $50^{\circ} \mathrm{C}$, while partial starch gelification took place in the concentration at $70^{\circ} \mathrm{C}$ and full gelification took place in the concentration at $90^{\circ} \mathrm{C}$. Gelification occurs when the starch granules are heated in water, which causes structural disorganization and an irreversible swelling of the granules (Singh et al., 2003). As the granules expand, the amylase inside the starch structure goes to the aqueous phase, which increases the system's rheological properties (Tharanathan, 2002). When maximum swelling is reached, the granules begin to rupture and, thus, viscosity decreases, a process that can be intensified at higher shear rates. Downgrading occurs during cooling, when solubilized polymers from starch associate into an ordered structure once again. Depending on the type and concentration of the starch, the final structure may be a thick solution or a gel (Singh et al., 2003; Eliasson, 2006). Therefore, 

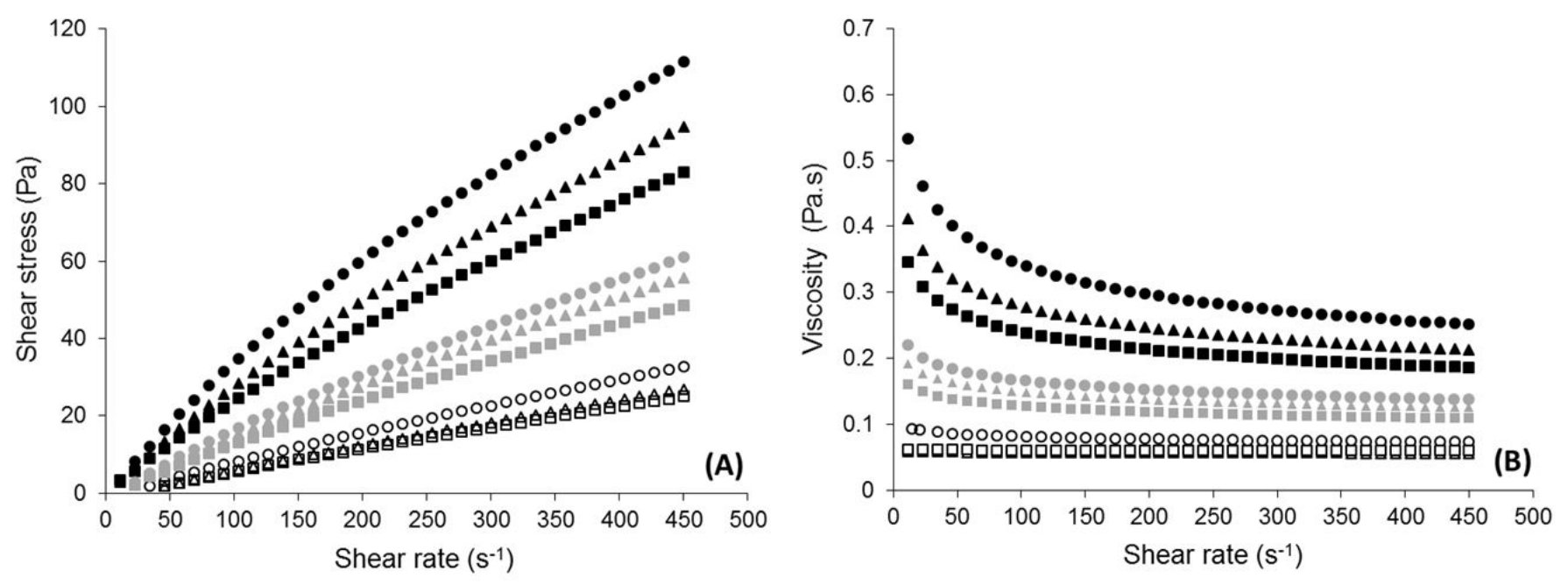

Figure 1. Effect of tucupi concentration and concentration temperature on the ratio between shear stress and shear rate (A) and between viscosity and shear rate (B). $30 \%$ solids $\left(\circ 50^{\circ} \mathrm{C}, \square 70{ }^{\circ} \mathrm{C}, \triangle 90^{\circ} \mathrm{C}\right) ; 35 \%$ solids $\left(50{ }^{\circ} \mathrm{C}, \square 70{ }^{\circ} \mathrm{C}, \Delta 90^{\circ} \mathrm{C}\right)$; and $40 \%$ solids $\left(50{ }^{\circ} \mathrm{C}, \boldsymbol{\square} 70^{\circ} \mathrm{C}, \boldsymbol{\Delta} 90^{\circ} \mathrm{C}\right.$ ).

as full starch gelification occurred in the tucupi concentrated at $90{ }^{\circ} \mathrm{C}$, its downgrading was also more marked, which justifies the behavior observed.

Irrespective of the concentration and concentration temperature, all concentrated tucupi samples showed typical non-Newtonian fluid behavior. The decreases in the tangent of the stress curves (Figure 1A) and of the viscosity curves (Figure 1B) as the shear rate applied increased classify the product as a pseudoplastic fluid (Schramm, 2000). Such effect was more visible as the product's concentration increased. Tecante \& Doublier (1999), Zimeri \& Kokini (2003), and Genccelep et al. (2015) observed a pseudoplastic fluid behavior for products with starch in their composition. This type of behavior was also observed by Horne (1998) and Lucey (2002) for protein-rich products. The pseudoplastic behavior can be explained by the weaker interactions among the molecules that make up the product as the shear rate applied increases, which leads to lower molecular interaction energy (Paseephol et al., 2008; Gozzo et al., 2009).

Figure 2 shows the flow curves ( $\tau$ versus $\gamma$ ) and viscosity curves ( $\eta$ versus $\gamma$ ) for tucupi with $40 \%$ solids, where the effects of concentration temperature $\left(50,70\right.$, and $90{ }^{\circ} \mathrm{C}$ ) and of the temperature at which the rheological analysis was carried out are assessed. According to the flow curves, when the rheological analysis was carried out starting at $40^{\circ} \mathrm{C}$, hysteresis, i.e., the area between the up-ramp and down-ramp curves (Holdsworth, 1993), were observed, which considerably increased with higher rheological analysis temperature. The fact that the down-ramp flow curves are above the up-ramp curves characterizes an increase in the product's viscosity over the shear time and shows an effect opposite to that of thixotropy, which is characteristic of rheopectic fluids (Holdsworth, 1993; Rao, 1999; Saravacos \& Maroulis, 2001). Starch suspensions may have thixotropic characteristics at low concentrations and rheopectic characteristics as the starch concentration in the suspension increases (Tattiyakul \& Rao, 2000).
Thixotropy is common for many fluids, while rheopexy is, indeed, very rare (Rao, 1999; Schramm, 2000). Rheopectic behavior is not commonly observed in foods, but has been observed in suspensions and concentrated starch pastes. Tárrega et al. (2005) observed a thixotropic behavior for gels with $4 \%$ modified corn starch and cassava starch, while a gel with $6 \%$ corn starch had rheopectic behavior. Tecante \& Doublier (1999) and Nayouf et al. (2003) observed rheopectic behavior for reticulated waxy corn starch pastes. Those authors suggest that the rheopectic behavior can be explained by a denser packaging of the starch granules as shear rates increase.

\subsection{Mathematical modeling}

Tables 1 and 2 present the values for the parameters of the fits of the rheological models to the experimental data obtained for concentrated tucupi in the different conditions studied. According to the results, the Ostwald-de Waele model had better fits $\left(\mathrm{R}^{2}>0.998 ; \chi^{2}<1.466\right.$; RMSE $\left.<0.194\right)$ than the Newton model $\left(\mathrm{R}^{2}>0.969 ; \chi^{2}<30.491 ; \mathrm{RMSE}<0.884\right)$ for the rheological data obtained at $25^{\circ} \mathrm{C}$ (Table 1). Under this condition, no hysteresis effect was observed. In the experimental conditions under which this phenomenon was observed $\left(40-80^{\circ} \mathrm{C}\right)$ (Table 2), the Ostwald-de Waele model had excellent fits to the data obtained with increasing (up-ramp) shear rates $\left(\mathrm{R}^{2}>0.997 ; \chi^{2}<1.005\right.$; RMSE $<0.163$ ). For the data observed with decreasing (down-ramp) shear rates, the fits of the Ostwald-de Waele model were also very good, however, they were impaired by higher temperature during rheological data acquisition: $40^{\circ} \mathrm{C}\left(\mathrm{R}^{2}>0.996 ; \chi^{2}<1.183\right.$; RMSE < 0.176), $60^{\circ} \mathrm{C}\left(\mathrm{R}^{2}>0.988 ; \chi^{2}<3.492\right.$; RMSE < 0.299), and $80^{\circ} \mathrm{C}\left(\mathrm{R}^{2}>0.953 ; \chi^{2}<17.185 ; \mathrm{RMSE}<0.672\right)$.

The values of the fluid behavior index (n) obtained by the Ostwald-de Waele model (Tables 1 and 2) confirm that, overall, concentrated tucupi behaved as a pseudoplastic fluid $(\mathrm{n}<1)$ regardless of the product's concentration or of the rheological analysis temperature. However, the increase in rheological 

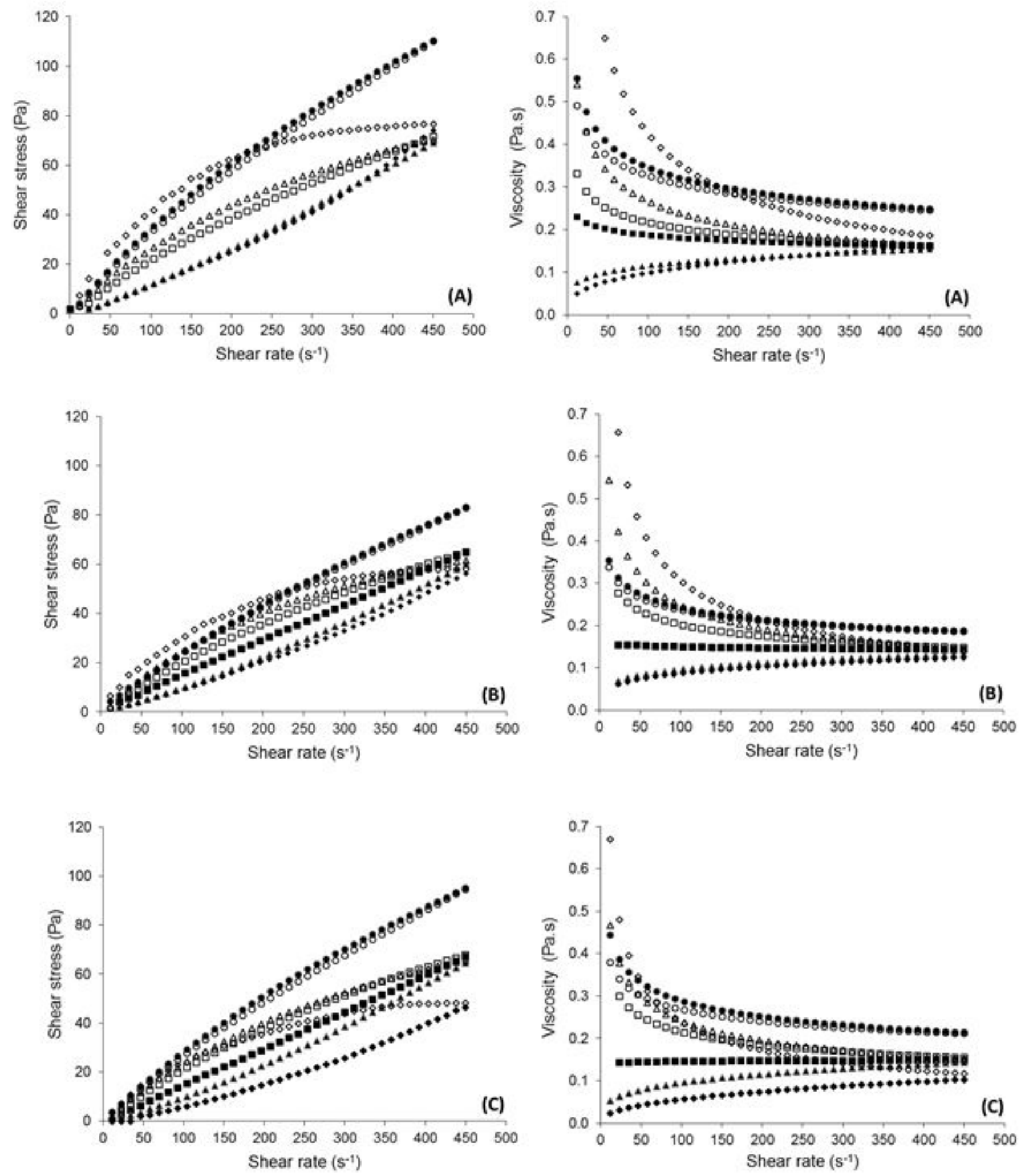

Figure 2. Ratio between shear stress and shear rate and between viscosity and shear rate for tucupi with $40 \%$ solids. Concentration temperature: (A) $50{ }^{\circ} \mathrm{C}$, (B) $70{ }^{\circ} \mathrm{C}$, and (C) $90^{\circ} \mathrm{C}$. Rheology temperature: (O) $25^{\circ} \mathrm{C}$ (up ramp); (O) $25^{\circ} \mathrm{C}$ (down ramp); ( $) 40{ }^{\circ} \mathrm{C}$ (up ramp); ( $\square$ ) $40{ }^{\circ} \mathrm{C}$

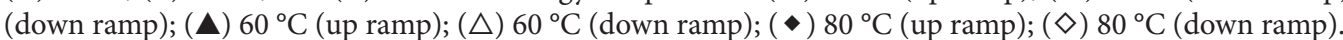


Table 1. Values of modeling parameters for the rheological data obtained at $25^{\circ} \mathrm{C}$ with the effect of tucupi concentration and concentration temperature.

\begin{tabular}{|c|c|c|c|c|c|c|c|c|c|c|}
\hline \multirow{3}{*}{ Model } & \multirow{3}{*}{ Parameter } & \multicolumn{9}{|c|}{ Tucupi concentration/Concentration temperature } \\
\hline & & \multicolumn{3}{|c|}{$30 \%$} & \multicolumn{3}{|c|}{$35 \%$} & \multicolumn{3}{|c|}{$40 \%$} \\
\hline & & $50^{\circ} \mathrm{C}$ & $70^{\circ} \mathrm{C}$ & $90^{\circ} \mathrm{C}$ & $50^{\circ} \mathrm{C}$ & $70^{\circ} \mathrm{C}$ & $90^{\circ} \mathrm{C}$ & $50^{\circ} \mathrm{C}$ & $70^{\circ} \mathrm{C}$ & $90^{\circ} \mathrm{C}$ \\
\hline \multirow[t]{4}{*}{ Newtonian } & $\eta($ Pa.s $)$ & $0.075^{\mathrm{f}}$ & $0.056^{\mathrm{g}}$ & $0.060^{g}$ & $0.143^{\mathrm{d}}$ & $0.113^{\mathrm{e}}$ & $0.130^{\text {de }}$ & $0.269^{\mathrm{a}}$ & $0.196^{c}$ & $0.226^{6}$ \\
\hline & $\mathrm{R}^{2}$ & $0.996^{\mathrm{ab}}$ & $0.998^{\mathrm{a}}$ & $0.998^{\mathrm{a}}$ & $0.988^{\mathrm{d}}$ & $0.992^{\mathrm{bc}}$ & $0.990^{\text {cd }}$ & $0.969^{f}$ & $0.981^{\mathrm{e}}$ & $0.978^{c}$ \\
\hline & $x^{2}$ & $0.356^{\mathrm{g}}$ & $0.077^{\mathrm{h}}$ & $0.080^{\mathrm{h}}$ & $3.356^{\mathrm{d}}$ & $1.398^{\mathrm{f}}$ & $2.342^{\mathrm{e}}$ & $30.491^{\mathrm{a}}$ & $10.519^{c}$ & 16.126 \\
\hline & RMSE & $0.098^{\mathrm{f}}$ & $0.046^{\mathrm{f}}$ & $0.047^{\mathrm{f}}$ & $0.297^{\mathrm{d}}$ & $0.192^{\mathrm{e}}$ & $0.248^{\mathrm{de}}$ & $0.884^{\mathrm{a}}$ & $0.519^{c}$ & $0.643^{t}$ \\
\hline \multirow{3}{*}{$\begin{array}{l}\text { Ostwald-de } \\
\text { Waele }\end{array}$} & $\mathrm{R}^{2}$ & $0.999^{\mathrm{a}}$ & $0.998^{\mathrm{a}}$ & $0.998^{\mathrm{a}}$ & $0.999^{a}$ & $0.999^{\mathrm{a}}$ & $0.999^{\mathrm{a}}$ & $0.998^{\mathrm{a}}$ & $0.999^{\mathrm{a}}$ & $0.999^{a}$ \\
\hline & $\chi^{2}$ & $0.105^{\mathrm{de}}$ & $0.074^{\mathrm{e}}$ & $0.082^{\mathrm{e}}$ & $0.286^{\mathrm{c}}$ & $0.125^{\mathrm{d}}$ & $0.268^{c}$ & $1.466^{\mathrm{a}}$ & $0.276^{c}$ & $0.687^{\mathrm{b}}$ \\
\hline & RMSE & $0.053^{\mathrm{d}}$ & $0.045^{\mathrm{d}}$ & $0.048^{\mathrm{d}}$ & $0.087^{\mathrm{c}}$ & $0.057^{\mathrm{cd}}$ & $0.084^{c}$ & $0.194^{\mathrm{a}}$ & $0.084^{c}$ & $0.133^{\mathrm{b}}$ \\
\hline
\end{tabular}

Mean values of the replicates with the same letters on the same row do not significantly differ among themselves ( $\mathrm{p} \leq 0.05)$ according to Tukey's test.

Table 2. Values of modeling parameters for the rheological data obtained for tucupi at $40 \%$ solids for the different concentration temperatures and rheological analysis temperatures.

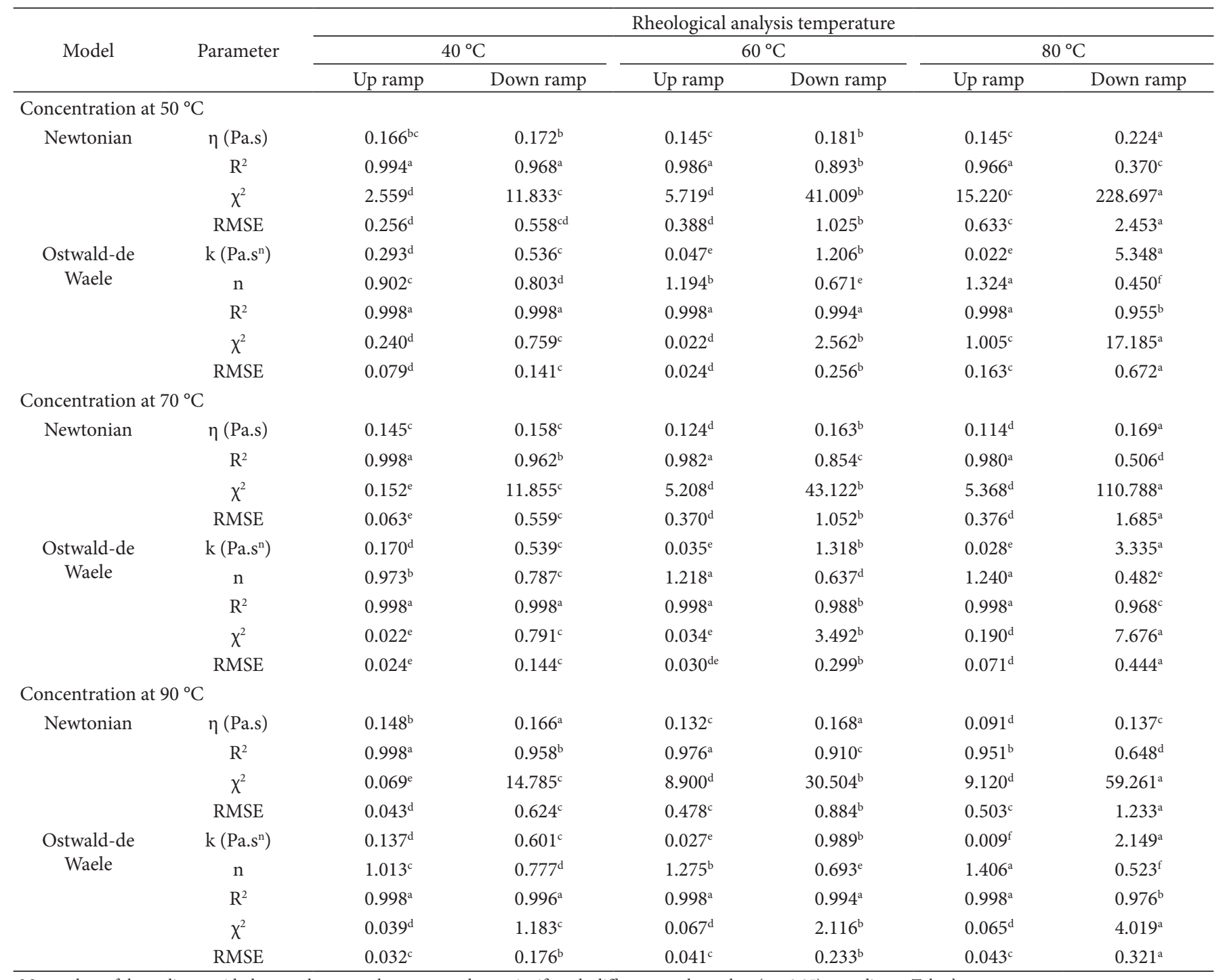

Mean values of the replicates with the same letters on the same row do not significantly differ among themselves ( $\mathrm{p} \leq 0.05)$ according to Tukey's test. 
analysis temperature had a greater impact on this behavior for the flow curves obtained with decreasing (down-ramp) shear rates. On the other hand, $n>1$ was observed for the flow curves obtained with increasing (up-ramp) shear rates when the rheological assays were carried out at $60^{\circ} \mathrm{C}$ and $80^{\circ} \mathrm{C}$. Under these conditions, the product behaved as a dilatant fluid and this behavior became more evident as temperature increased both in the product concentration and in the rheological analysis.

Overall, the fluid's consistency index $(\mathrm{k})$ decreased as the product's concentration temperature and rheological analysis temperature increased for the flow curves obtained with increasing (up-ramp) shear rates. In turn, the value of $k$ increased as the rheological analysis temperature increased for all flow curves obtained with decreasing (down-ramp) shear rates regardless of the concentration temperature.

From a process point of view, operations such as pumping and filling of concentrated tucupi or sauces based on tucupi will be facilitated by conditions in which the product behaves as a pseudoplastic fluid. On the other hand, under conditions in which the product behaves as a dilatant fluid, these operations will be hampered (Rao, 2014).

\subsection{Activation energy}

The Arrhenius-like equation (Equation 4) represented very well the effect of temperature on apparent viscosity calculated by the Ostwald-de Waele model for the rheological data obtained with increasing (up-ramp) shear rates $\left(\mathrm{R}^{2}>0.96\right)$. On the other hand, for the data obtained with decreasing (down-ramp) shear rates, the fits were very poor $\left(R^{2}<0.21\right)$. Thus, only the rheological data obtained with increasing shear rates can be used to calculate the activation energy $\left(\mathrm{E}_{\mathrm{a}}\right)$.

The $\mathrm{E}_{\mathrm{a}}$ values calculated for a shear rate of $100 \mathrm{~s}^{-1}$ were: $20.11 \mathrm{~kJ} / \mathrm{mol}$ for the product concentrated at $50^{\circ} \mathrm{C} ; 16.86 \mathrm{~kJ} / \mathrm{mol}$ for the product concentrated at $70{ }^{\circ} \mathrm{C}$, and $25.23 \mathrm{~kJ} / \mathrm{mol}$ for the product concentrated at $90^{\circ} \mathrm{C}$. Coutinho \& Cabello (2005) observed an $\mathrm{E}_{\text {a }}$ value of $19.48 \mathrm{~kJ} / \mathrm{mol}$ for a gel with $10 \%$ cassava starch. According to Rao (1999), polysaccharide gels can have $\mathrm{E}_{\mathrm{a}}$ values between 10 and $273 \mathrm{~kJ} / \mathrm{mol}$. $\mathrm{E}_{\mathrm{a}}$ values indicate the sensitivity of a rheological parameter as a function of temperature and the higher the $\mathrm{E}_{\mathrm{a}}$ values, more sensitive a product is to rheological changes (Steffe, 1996). Therefore, the viscosity of the product concentrated at $90^{\circ} \mathrm{C}$ showed the highest thermal sensitivity while the viscosity of the product concentrated at $70^{\circ} \mathrm{C}$ was less susceptible to the effect of temperature.

\section{Conclusion}

The rheological study of concentrated tucupi showed that the product concentration at a temperature above $70^{\circ} \mathrm{C}$ increases the product's viscosity and that, in general, concentrated tucupi behaves as a pseudoplastic fluid. Additionally, hysteresis were observed between the up-ramp and down-ramp flow curves at temperature from $40{ }^{\circ} \mathrm{C}$, showing that concentrated tucupi is characterized as a rheopectic fluid. The Ostwald-de Waele model predicted with excellent accuracy the flow curves of the analyzed product and the dependence of apparent viscosity on temperature was well described by an Arrhenius-like equation. The activation energy values calculated for concentrated tucupi ranged from $16.86 \mathrm{~kJ} / \mathrm{mol}$ to $25.23 \mathrm{~kJ} / \mathrm{mol}$.

\section{Acknowledgements}

The authors would like to thank $\mathrm{CNPq}$ (Conselho Nacional de Desenvolvimento Científico e Tecnológico) (473898/2012-8) and PROPESP/UFPA for the financial support.

\section{References}

Abu-Jdayil, B., Al-Malah, K., \& Asoud, H. (2002). Rheological characterization of milled sesame. Food Hydrocolloids, 16(1), 55-61. http://dx.doi.org/10.1016/S0268-005X(01)00040-6.

Association of Official Analytical Chemists - AOAC. (2010). Official methods of analysis of association of Official Analytical Chemists International (18th ed.). Arlington: AOAC.

Brennan, J. G., Butters, J. R., \& Cowell, N. D. (1999). Las operaciones de la ingeniería de los alimentos (3th ed.). Zaragoza: Acribia.

Chisté, R. C., Cohen, K. O., \& Oliveira, S. S. (2007). Study of tucupi physicochemical properties. Food Science and Technology, 27(3), 437-440. http://dx.doi.org/10.1590/S0101-20612007000300002.

Costa, T. S., Carmo, J. R., Braga, A. C. C., \& Pena, R. S. (2017a). Tucupi creamy paste: development, sensory evaluation and rheological characterization. Food Science and Technology, 37(Suppl. 1), 115124. http://dx.doi.org/10.1590/1678-457x.34516.

Costa, T. S., Carmo, J. R., \& Pena, R. S. (2017b). Powdered tucupi condiment: sensory and hygroscopic. Food Science and Technology, 38(1), 33-40. http://dx.doi.org/10.1590/1678-457x.36816.

Coutinho, A. P. C., \& Cabello, C. (2005). Caracterização reológica da fécula de mandioca. Revista Raízes e Amidos Tropicais, 1, 40-48. http://dx.doi.org/10.17766/1808-981X.2005v1n1p40-48.

Eliasson, A. C. (2006). Carbohydrates in food (2nd ed.). Boca Raton: CRC Press.

Genccelep, H., Saricaoglu, F. T., Anil, M., Agar, B., \& Turhan, S. (2015). The effect of starch modification and concentration on steady-state and dynamic rheology of meat emulsions. Food Hydrocolloids, 48, 135-148. http://dx.doi.org/10.1016/j.foodhyd.2015.02.002.

Gozzo, A. M., Cunha, R. L., \& Menegalli, F. C. (2009). Viscosidade extensional e em cisalhamento de suspensões acidificadas de amido de amaranto e caseinato de sódio. Food Science and Technology, 29(3), 587-596. http://dx.doi.org/10.1590/S0101-20612009000300021.

Holdsworth, S. D. (1993). Rheological models used for the prediction of the flow properties of food products: a literature review. Transactions of the Institution of Chemical Engineers, 71, 139-179.

Hoover, R. (2001). Composition, molecular structure, and physicochemical properties of tuber and root starches: a review. Carbohydrate Polymers, 45(3), 253-267. http://dx.doi.org/10.1016/S0144-8617(00)00260-5.

Horne, D. S. (1998). Casein interactions: casting light on the Black Boxes, the structure in dairy products. International Dairy Journal, 8(3), 171-177. http://dx.doi.org/10.1016/S0958-6946(98)00040-5.

Ibarz, A., \& Cánovas, G. V. B. (2002). Unit operations in food engineering. Boca Raton: CRC Press.

Lucey, J. A. (2002). Formation and physical properties of milk protein gels. Journal of Dairy Science, 85(2), 281-294. http://dx.doi.org/10.3168/ jds.S0022-0302(02)74078-2. PMid:11913691.

Nayouf, M., Loisel, C., \& Doublier, J. L. (2003). Effect of thermomechanical treatment on the rheological properties of crosslinked waxy corn starch. Journal of Food Engineering, 59(2-3), 209-219. http://dx.doi. org/10.1016/S0260-8774(02)00460-0.

Paseephol, T., Small, D. M., \& Sherkat, F. (2008). Rheology and texture of set yogurt as affected by inulin addition. Journal of Texture Studies, 39(6), 617-634. http://dx.doi.org/10.1111/j.1745-4603.2008.00161.x. 
Pires, F. C. S., \& Silva Pena, R. (2017). Optimization of spray drying process parameters for tucupi powder using the response surface methodology. Journal of Food Science and Technology, 54(11), 34593472. http://dx.doi.org/10.1007/s13197-017-2803-5. PMid:29051641.

Rao, A. M. (1999). Rheology of fluid and semisolid fluids: principles and applications. Gaithersburg; Aspen Publication Inc.

Rao, M. A. (2014). Rheological properties of fluid foods. In M. A. Rao, S. S. H. Rizvi, A. K. Datta \& J. Ahmed (Eds.), Engineering properties foods Boca Raton: CRC Press. http://dx.doi.org/10.1201/b16897-6.

Saravacos, D. G., \& Maroulis, Z. B. (2001). Transport properties of food. New York: Marcel Dekker.

Schramm, G. A. (2000). A practical approach to rheology and rheometry (2nd ed.). Karlsruhe: Gebrueder Haake.

Silva, F. C., Guimarães, D. H. P., \& Gasparetto, C. A. (2005). Rheology of acerola juice: effects of concentration and temperature. Food Science and Technology, 25(1), 121-126. http://dx.doi.org/10.1590/ S0101-20612005000100020.

Singh, N., Singh, J., Kaur, L., Singh Sodhi, N., \& Singh Gill, B. (2003). Morphological, thermal and rheological properties of starches from different botanical sources. Food Chemistry, 81(2), 219-231. http:// dx.doi.org/10.1016/S0308-8146(02)00416-8.
Steffe, J. F. (1996). Rheological methods in food process engineering (2nd ed.). East Lansing: Freeman Press.

Tárrega, A., Vélez-Ruiz, J. F., \& Costell, E. (2005). Influence of milk on the rheological behaviour of cross-linked waxy maize and tapioca starch dispersions. Food Research International, 38(7), 759-768. http://dx.doi.org/10.1016/j.foodres.2005.03.002.

Tattiyakul, J., \& Rao, M. A. (2000). Rheological bahavior of crosslinked waxy maize starch dispersion during and after heating. Carbohydrate Polymers, 43(3), 215-222. http://dx.doi.org/10.1016/ S0144-8617(00)00160-0.

Tecante, A., \& Doublier, J. L. (1999). Steady flow and viscoelastic behavior of crosslinked waxy corn starch-k-carrageenan pastes and gels. Carbohydrate Polymers, 40(3), 221-231. http://dx.doi.org/10.1016/ S0144-8617(99)00057-0.

Tharanathan, R. N. (2002). Food-derived carbohydrates - Structural complexity and functional diversity. Critical Reviews in Biotechnology, 22(1), 65-84. http://dx.doi.org/10.1080/07388550290789469. PMid:11958336.

Zimeri, J. E., \& Kokini, J. I. (2003). Rheological properties of inulinwaxy maize starch systems. Carbohydrate Polymers, 52(1), 67-85. http://dx.doi.org/10.1016/S0144-8617(02)00268-0. 